\title{
Chance that matter or matter of chance: changing prevalence of fundic gland polyps and proton pump inhibitors
}

\author{
Zeeshan Wani ${ }^{1}$, Muzzafer Mir², Afaq Khan ${ }^{3}$, Iqbal Baba4, Showkat Mir ${ }^{5}$, Majid Rather ${ }^{6}$, \\ Shaheen Lone ${ }^{7}$, Akhter Raina ${ }^{8}$ \\ ${ }^{1}$ Assistant Professor, ${ }^{6}$ DNB Scholar, ${ }^{7}$ Registrar, Department of Gastroenterology, Srinagar, Jammu Kashmir, India, \\ ${ }^{2}$ Consultant Gastroenterologist, Department of Gastroenterology, Noora super-speciality, Hospital, Srinagar, Jammu \\ Kashmir, India, ${ }^{3}$ Assistant Professor, Department of Haematology, Sheri Kashmir Institute of Medical Science, Srinagar; \\ Jammu Kashmir, India, ${ }^{4}$ Assistant Professor, Department of Pathology, Government Medical College Baramulla, \\ Jammu Kashmir, India, ${ }^{5}$ Consultant Pathologist, ${ }^{8}$ Consultant Medicine, Department of Health and Medical Education, \\ Jammu Kashmir, India
}

A B S T R A C T

Background: Proton pump inhibitors (PPI) are considered one of reasons for changing prevalence of gastric fundic gland polyps (FGP), not only in western world but trend is being seen in Asian countries as well. Aims and Objective: This study was designed to evaluate prevalence of FGP and to look into endoscopic and histological profile of these polyps in PPI users and non-PPI users. We also assessed background gastric mucosal histology in FGP patients. Materials and Methods: This is a retrospective observational study of 1800 cases. Medical records of patients who underwent esophagogastroduodenoscopy (EGD) in three gastroenterology centres between 2011 and 2019 were analysed at Noora super speciality Hospital, Kashmir; Northern India. Biopsy specimens of patients with FGP were reviewed by expert pathologists. PPI use was quantified as significant when Pantoprazole $40 \mathrm{mg}$ per day or equivalent doses of other PPI was used four times or more per week for more than one year. Statistical Analysis was conducted using SPSS version 22. Results: FGP were most common, observed in $900(50 \%)$ of all gastric polyp cases. PPI use one year and more was noted only in 360 (40\%). FGP were mostly located in fundus 630 (70\%), multiple in 840 $(93.33 \%)$, with average size between 6 to $10 \mathrm{~mm}$. On histology parietal cell hyperplasia, parietal cell protrusion and foveolar hyperplasia were seen in $666(74 \%), 716(79.55 \%)$ and 254 (28.22\%) cases respectively. Background gastric histology was normal in 543 (60.33\%). Conclusions: FGP were most common gastric polyps in Northern India. We observed similar endoscopic and histological characters in FGP irrespective of whether cases were using PPI or not. Majority of cases had normal background gastric mucosal histology.

Key words: Fundic Gland Polyps; Gastric Polyps; Helicobacter pylori; Prevalence; Proton Pump Inhibitors

\section{INTRODUCTION}

Over past several decades histologic profile of gastric polyps had changed altogether. Previous literature showed hyperplastic polyps (Hpp) very common outnumbering gastric fundic gland polyps (FGP) but enormous literature has accumulated in west beyond 2009 reflecting changing

\section{Access this article online}

Website:

http://nepjol.info/index.php/AJMS DOI: 10.3126/ajms.v12i5.34418

E-ISSN: 2091-0576

P-ISSN: 2467-9100

Copyright (c) 2021 Asian Journal of Medical Sciences

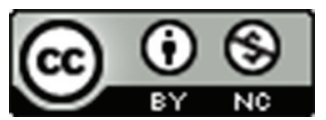

This work is licensed under a Creative Commons Attribution-NonCommercial 4.0 International License. 
located usually in the proximal stomach. Surface color of FGP is translucent or hypermic and usually matches normal gastric mucosa. ${ }^{8,9}$ Endoscopic appearances are diagnostic with $89-90 \%$ accuracy. ${ }^{10}$ On microscopy, they have dilated glands and small cysts lined by gastric body mucosal cells like parietal and chief cells with insignificant inflammation. ${ }^{10,11}$ Associated gastric mucosal abnormalities like chronic inactive gastritis (C.I.G) and Helicobacter pylori (H. pylori) gastritis are also seen. ${ }^{12}$ Also FGP histologically can be easily differentiated from hyperplastic, adenomatous and other polyp like lesions. ${ }^{10,11}$

It is believed that changing trend in FGP was due to aggressive use of proton pump inhibitors (PPI) in both western and Asian countries. ${ }^{3-5,7}$ Still researchers are trying to find out definitive histological, elaborative genetic and environmental differences between non-PPI and PPI associated FGP.

Our study has tried not only to look into current trends in prevalence of FGP but also endoscopic appearance and histologic pattern with respect to PPI use in those cases. Note of concomitant gastric histology was also made.

\section{METHODS AND MATERIALS}

Ourstudyis a retrospective observational study. Medical records of patients who underwent esophagogastroduodenoscopy (EGD) in three gastroenterology centres between 2011 and 2019 were analysed at Noora super speciality Hospital, Kashmir; Northern India. Biopsy specimens of patients with FGP were reviewed by expert pathologists. Polyps were either biopsied or removed at time of endoscopy. Patients whose gastric biopsies were not assessed and properly graded as per the Sydney protocol were excluded from the study. PPI use was described on basis of doses and duration of PPI. PPI use was quantified as significant when Pantoprazole $40 \mathrm{mg}$ per day or equivalent doses of other PPI was used four times or more per week for more than one year. Accordingly cases were grouped as PPI use group (with significant PPI use) and others as non-PPI use group. Histopathologic diagnoses of FGP were reviewed by expert pathologists and histopathologic features were analysed in all polyps for:

1. Type of cells in cyst epithelial lining like parietal cell, chief cell and other mucous cell.

2. Parietal cell and superficial foveolar epithelium changes (hyperplasia or protrusions of parietal cell and foveolar hyperplasia).

3. Glands for secretion and atrophy, epithelial cell changes like metaplasia or dysplasia.

4. Type of inflammation: chronic inflammatory infiltrate in lamina propria.

5. H. pylori infection.
Inclusion criteria

The inclusion criteria of the study were biopsy proven fundic gland polyps.

\section{Exclusion criteria}

The exclusion criteria were known malignancy, syndromic polyps on clinical grounds, cases in which gastric mucosal biopsies were not taken as per Sydney protocol.

\section{STATISTICS}

Statistical Analysis was conducted using SPSS version 22 for Windows (SPSS, Chicago, IL). Categorical variables estimation was done by using the chi-square or Fisher's exact test., continuous data by t-test or the Mann-Whitney test and the Kruskal-Wallis test was used for multiple comparisons. Quantitative variables with a normal distribution were represented as mean values \pm standard deviation and those with a non-normal distribution as median values (range). Significance levels were done twosided and set to less than 0.05 .

\section{ETHICAL CLEARANCE}

Permission for study was taken from Institutional review committee number/ date EC-1971 dated 7/1/2019. Identity of patients has not been disclosed while presenting this data.

\section{RESULT}

Of the 1800 cases with polyps, relative prevalence of FGP was $900(50 \%)$. In cases with FGP synchronous polyp were seen in 7; Hpp in 4, adenomatous polyps in 2 and xanthomas in 1 case. Mean age of presentations was 51.42 years, lowest of 13 years and highest of 89 years, in which $579(64.30 \%)$ were male and $321(35.70 \%)$ female. Out of 900 FGP cases, $250(27.80 \%)$ were smokers. The most frequent presenting complaint in cases with FGP was dyspepsia followed by anemia. PPI use was seen in $360(40 \%)$ of cases with FGP as in (Table 1).

The distribution, size and number of FGP in the stomach are given in Table 2. FGP were most common in the fundus and cardia. In PPI use group FGP were more frequent in fundus, smaller in size and less likely multiple than nonPPI group. However, none of these parameters reached significant level ( $\mathrm{p}$ value $>0.05$ ).

On histopathologic examination typical changes of FGP were noted in both non-PPI use and PPI use groups. 
Parietal cell hyperplasia, parietal cell protrusion and foveolar hyperplasia varied in non-PPI use and PPI use groups but were insignificant ( $\mathrm{p}$ value $>0.05$ ) as in Table 3 . In PPI use group cyst lining was more often lined by mixed type gastric cell and had Parietal cell protrusion on other hand in non-PPI use group cyst lining was more often lined by Oxyntic type gastric cell, more often had Parietal cell hyperplasia and Foveolar hyperplasia. However, none of these differences reached significant level $(p$-value $\leq 0.05)$ as shown in Table 3. H. pylori infections have similar frequency in both groups.

Background gastric mucosal histology was normal in majority of patients $543(60.33 \%)$. One seventy-one $(19 \%)$ have non-specific gastritis i.e., chronic inactive gastritis. H. pylori infection was seen in 7.5\% FGP cases as in Table 4.

\section{DISCUSSION}

FGP are being increasingly reported because of speculative association with prolonged PPI therapy and some possible

\begin{tabular}{lcc}
\multicolumn{3}{l}{ Table 1: Clinical profile of patients with FGP } \\
\hline Clinical profile & $\mathbf{n}$ & percentage \\
\hline Males & 579 & 64.30 \\
Females & 321 & 35.70 \\
Smoker & 250 & 27.80 \\
Symptoms and signs & & \\
Anemia & 138 & 15.30 \\
Dyspepsia & 568 & 63.20 \\
GERD & 44 & 4.80 \\
FOBP & 57 & 6.30 \\
Hematemesis & 45 & 5 \\
Melena & 48 & 5.30 \\
non-PPI use FGP & 540 & 60 \\
No PPI use & 396 & 73.40 \\
Occasional and less than 1 year & 144 & 26.60 \\
PPI use associated FGP & 360 & 40 \\
\hline GERD=Gastroesophageal reflux disease, FOBP=Fecal occult blood test positive, \\
PPI=Proton pump inhibitors, FGP=Gastric fundic gland polyps
\end{tabular}

\begin{tabular}{lccc}
\multicolumn{4}{l}{ Table 2: Relation of polyp location, size and } \\
number in non -PPI and PPI use groups \\
\hline Polyp variable & $\begin{array}{c}\text { non-PPI use } \\
\text { group }\end{array}$ & $\begin{array}{c}\text { PPI use } \\
\text { group }\end{array}$ & p-value \\
\hline Location of polyp & $\mathrm{n}=540$ & $\mathrm{n}=360$ & 0.65 \\
Fundus/Cardia & $370(68.51 \%)$ & $253(70.27 \%)$ & \\
Corpus & $102(18.88 \%)$ & $67(18.61 \%)$ & \\
Antrum & $64(11.85 \%)$ & $38(10.55 \%)$ & \\
Pylorus & $4(0.74 \%)$ & $2(0.55 \%)$ & 0.89 \\
Size of polyp & & & \\
1-5 mm & $402(74.44 \%)$ & $251(69.72 \%)$ & \\
6-10 mm & $120(22.22 \%)$ & $96(26.66 \%)$ & \\
Greater than $10 \mathrm{~mm}$ & $18(3.33 \%)$ & $13(3.6 \%)$ & 0.99 \\
Number of polyps & & $32(8.88 \%)$ & \\
Single & $27(5 \%)$ & $328(91.11 \%)$ & \\
multiple & $513(95 \%)$ & & \\
\hline
\end{tabular}

increase in frequency in recent decades. ${ }^{13}$ Reportedly these are commonest seen gastric polyps in studies from west. ${ }^{14,15}$ Study of gastric polyps of 5515 patients over a 20-year period, by Stolte et al in $1994^{16}$, the incidence of FGP was 47\%. In contrast, in 1996, Archimandritis from Greece $^{1}$ reported that majority of polyps were Hpp $(75 \%)$. In another study, by Morais DJ et al., ${ }^{2} 2007$ in Brazil, $70 \%$ of gastric polyps were Hpp and 16\% were FGP. Deppisch et al. ${ }^{17}$ in 1998 reported Hpp prevalence of $75 \%$ from the USA. However, Carmack et al., ${ }^{12}$ in 2009 from United States published large series that reported dramatic change in relative prevalence of gastric polyps with FGP being most common type constituting $77 \%$.

FGP constitutes $50 \%$ of 1800 gastric polyps in this study from Northern Indian population which is much higher than reported in the earlier literature in many parts of world. ${ }^{1,2,17}$ Given the possible widespread use of PPI in Northern India especially in Jammu Kashmir because of typical spicy dietary habits, over the counter use and free availability of PPI even in remote areas of this state, and probably increased $\mathrm{H}$. pylori eradication in previous decade can be possible explanations. ${ }^{6,7}$

In 1989 FGP represented $17 \%$ of all gastric polyps in United States $^{17}$ and $10 \%$ in France. ${ }^{18}$ The highest relative prevalence in the literature is $47 \%$ reported in a 20 year German study. ${ }^{16}$ In our series FGP made up 50\% as mentioned above. FGP were possibly thought to be hemartoma and tend to arise in patients with $\mathrm{H}$. pylori free stomachs and those receiving chronic PPIs treatment. ${ }^{3-5} \mathrm{In}$ our study, only $7.6 \%$ have $\mathrm{H}$. Pylori gastritis.

In our study, though $60 \%$ of cases had background histology of stomach normal, $19 \%$ of patients had chronic inactive gastritis (CIG) so it may be concluded that some forms of gastritis may increase the risk of gastric polyp, but this needs further research for validation.

The explanation for increasing trend of FGP may be the changing trend in PPI use and aggressive H. pylori treatment. ${ }^{6,13,19-21}$ Gastric polyps seem to be undergoing epidemiological change with the frequency of FGP increasing from $19 \%(15 / 80)$ to $77 \%(638 / 828)$ whereas Hpp decreased from $65 \%(52 / 80)$ to $15 \%(123 / 828) .{ }^{21}$ However, our study may be biased by the inclusion of more patients with dyspepsia and excessive PPIs use in the cases. More polyps were observed in adult males possibly because of more males in this study. However further research will is needed to look for gender susceptibility for polyp formation

The mechanisms of rising prevalence of PPI use associated FGP may be genetic mutations or Hypergastrinemia. FGP genesis seems to be associated with prolonged PPI use. $4,22,23$ 


\begin{tabular}{|c|c|c|c|c|}
\hline \multirow[b]{2}{*}{ Pathologic features } & \multicolumn{2}{|c|}{ non-PPI use group } & \multicolumn{2}{|l|}{ PPI use group } \\
\hline & no PPI use $(n=396)$ & occasional PPI use $(n=144)$ & PPI use $\geq 1$ year $(n=360)$ & $p$-value \\
\hline Cyst lining & & & & 0.99 \\
\hline Mixed & $204(51.51 \%)$ & $79(54.86 \%)$ & $186(51.66 \%)$ & \\
\hline Oxyntic & $150(37.87 \%)$ & $65(45.13 \%)$ & $174(48.33 \%)$ & \\
\hline Parietal cell hyperplasia & & & & 0.99 \\
\hline Positive & $303(76.51 \%)$ & $108(75 \%)$ & $223(61.94 \%)$ & \\
\hline Negative & $137(34.59 \%)$ & $36(25 \%)$ & $137(38.05 \%)$ & \\
\hline Parietal cell protrusion & & & & 0.32 \\
\hline Positive focal & $160(40.4 \%)$ & $61(42.36 \%)$ & $162(45 \%)$ & \\
\hline Positive diffuse & $40(10.1 \%)$ & $12(8.33 \%)$ & $38(10.55 \%)$ & \\
\hline Negative & $196(49.49 \%)$ & $71(49.30 \%)$ & $160(44.44 \%)$ & \\
\hline Mucus plug & & & & 0.66 \\
\hline Positive & $127(32.07 \%)$ & $51(35.41 \%)$ & $127(35.27 \%)$ & \\
\hline Negative & $296(67.92 \%)$ & $93(64.58 \%)$ & $233(64.72 \%)$ & \\
\hline Foveolar hyperplasia & & & & 1.1 \\
\hline Positive & $160(40.9 \%)$ & $65(45.13 \%)$ & $148(41.11 \%)$ & \\
\hline Negative & $236(59.59 \%)$ & $79(54.86 \%)$ & $212(58.88 \%)$ & \\
\hline H. pylori infection & & & & 0.45 \\
\hline Positive & $26(6.5 \%)$ & $14(9.72 \%)$ & $28(7.77 \%)$ & \\
\hline negative & $370(93.43 \%)$ & $130(90.27 \%)$ & $332(92.22 \%)$ & \\
\hline
\end{tabular}

\begin{tabular}{|c|c|c|}
\hline Gastric histology & $\mathbf{n}$ & Percentage (\%) \\
\hline Normal gastric mucosa & 543 & $60.33 \%$ \\
\hline Chronic inactive gastritis & 171 & $19 \%$ \\
\hline Reactive gastritis & 78 & $8.7 \%$ \\
\hline Helicobacter pylori gastritis & 68 & $7.5 \%$ \\
\hline Intestinal Metaplasia & 37 & $4.1 \%$ \\
\hline Portal hypertensive gastritis & 3 & $0.3 \%$ \\
\hline
\end{tabular}

Cats et al in their study showed appearance of parietal cell protrusions, proliferation and glandular changes in patients on prolonged PPI therapy. ${ }^{24}$ These changes were seen in $18 \%$ of patients with early treatment and $86 \%$ of patients over one year. Jalving et al., ${ }^{25}$ have also shown somewhat similar results. However, this hypothesis of acid suppression with PPI leading to FGP is refuted by many researchers. ${ }^{26,27}$ Hypergastrinemia, secondary to PPI chronic use can lead to parietal cell proliferation and hyperplasia. ${ }^{24}$ FGP can results from a dual mechanism of cellular proliferation and obstruction of glandular secretion flow, both related to PPI therapy. ${ }^{28}$

Parietal cell changes like protrusion $(60 \%)$ and hyperplasia $(70 \%)$ were seen in cases with FGP in our study were similar in both PPI use and non-PPI use groups. Cysts were lined by a mixed cell population in around $50 \%$ of cases which include parietal, chief and mucous foveolar-type cells. These findings are the classical histological picture of FGP, with disorganized glands, which substantiated the classification of these lesions as hamartomatous in the past. ${ }^{14,29}$ Foveolar hyperplasia was observed in $40 \%$ of cases. True proliferative changes of foveolar epithelium related mostly to chronic active gastritis and $\mathrm{H}$. pylori infection. Mucous plugs in glands and exfoliated cells in almost half $(33 \%)$ of our sample provide support to the glandular flow obstruction hypothesis for FGP development. ${ }^{29}$

About half of polyps (50\%) have cysts lined by parietal/ chief cells only. Some of these cases showed tiny cysts in a background of hyperplastic and hypertrophied oxyntic mucosa with parietal cell protrusions, a histological change frequently described in non-polypoid gastric mucosa of chronic PPI users. ${ }^{24,25,30}$ Nevertheless, no specific morphologic markers were seen in PPI use FGP group in our study, as nearly similar architectural changes were noted in non-PPI use FGP group. These morphologic changes in oxyntic mucosa have also been recently linked to $\mathrm{H}$. pylori chronic gastritis. ${ }^{31}$ The exact causative role of PPI therapy in oxyntic cell changes is still a under review. ${ }^{32}$

H. pylori infection was detected in $68(7.5 \%)$ of cases in our study which corroborates the well-known inverse association of FGP and this bacterium. Genta et al., ${ }^{33}$ found frequency of $\mathrm{H}$. pylori infection in $0.5 \%$. In fact, acquisition of $\mathrm{H}$. pylori infection can cause regression of FGP. ${ }^{34}$

Advance epithelial changes like metaplasia or beyond were not identified in any case in 900 fundic gland polyps examined in the study. So our study support paradigm of FGP being benign proliferative lesion, no matter it may show some Neoplastic-like features at molecular level.

We compared two groups endoscopically with respect to number, size and location of polyp to see any specific relation with PPI use associated FGP. There was no 
significant statistical difference between number, size and location of polyps between PPI and non-PPI use group with $\mathrm{p}$ value $\geq 0.05$ in all as in Table 2 .

\section{CONCLUSION}

Our study describes the changing relative prevalence of different gastric polyps in a Northern Indian population. There is rising trend of FGP possibly signifying increasing PPI use and H. pylori eradication therapy. Parietal cell, glandular and epithelial changes were detected in PPI use and non-PPI use groups with insignificant differences.

\section{ACKNOWLEDGEMENT}

The authors take this opportunity to thank Department of Gastroenterology, Pathology and Medicine for their whole hearted support for this study

\section{REFERENCES}

1. Archimandritis A, Spiliadis C, Tzivras M, Vamvakousis B, Davaris P, Manika Z, et al. Gastric epithelial polyps: a retrospective endoscopic study of 12974 symptomatic patients. Ital J Gastroenterol. 1996;28(7):387-390.

2. Morais DJ, Yamanaka A, Zeitune JMR and Andreollo NA. Gastric polyps: A retrospective analysis of 26,000 digestive endoscopies. Arq Gastroenterol Y. 2007; 44(1): 14-17. https://doi.org/10.1590/S0004-28032007000100004

3. Freeman HJ. Proton pump inhibitors and an emerging epidemic of gastric fundic gland polyposis. World J Gastroenterol. 2008; 14:1318-1320. https://doi.org/10.3748/wjg.14.1318

4. El-Zimaity HM, Jackson FW and Graham DY. Fundic gland polyps developing during omeprazole therapy. Am J Gastroenterol. 1997; 92:1858-1860.

5. Raghunath AS, O'Morain C and McLoughlin RC. Review article: the long-term use of proton-pump inhibitors. Aliment Pharmacol Ther. 2005; 22(Suppl 1):55-63.

https://doi.org/10.1111/j.1365-2036.2005.02611.x

6. Wani ZA, Mir MM, Rather MK, Lone SN, Mir TA and Raina AA. Gastric Polyps in North India: Prevalence, Pattern and Beyond. Gastroenterol Hepatol Int J. 2020; 5(1): 000167.

7. Wani ZA, Mir MM, Raina AA, Lone SN and Taranum UM. Changing prevalence of gastric fundic gland polyps: current scenario in North India. International Journal of Contemporary Medical Research. 2019;6 (10) :J1-J5. https://doi.org/10.21276/ ijcmr.2019.6.10.40

8. Goddard AF, Badreldin R, Pritchard DM, Walker MM and Warren B. British Society of Gastroenterology. The management of gastric polyps. Gut. 2010; 59:1270-1276.

https://doi.org/10.1136/gut.2009.182089

9. Burt RW. Gastric fundic gland polyps. Gastroenterology. 2003; 125:1462-1469. https://doi.org/10.1016/j.gastro.2003.07.017

10. Weston BR, Helper DJ and Rex DK. Positive predictive value of endoscopic features deemed typical of gastric fundic gland polyps. J Clin Gastroenterol. 2003; 36:399- 402. https://doi.org/10.1097/00004836-200305000-00007

11. Chandrasekhara $V$ and Ginsberg GG. Endoscopic management of gastrointestinal stromal tumors. Curr Gastroenterol Rep. 2011; 13:532-539. https://doi.org/10.1007/s11894-011-0224-6

12. Susanne W. Carmack, Genta RM, Schuler CM and Saboorian $\mathrm{MH}$. The current spectrum of gastric polyps: a 1-year national study of over 120,000 patients. Am J Gastroenterol. 2009; 104:1524-1532

https://doi.org/10.1038/ajg.2009.139

13. Cao H, Wang B, Zhang Z, Zhang $H$ and Qu R. Distribution trends of gastric polyps: An endoscopy database analysis of 24 121 northern Chinese patients. J Gastroenterol Hepatol. 2012; 27:1175-1180.

https://doi.org/10.1111/j.1440-1746.2012.07116.x

14. Lauwers GY, Carneiro F, Graham DY, Curado MP, Franceschi S, Montgomery E, et al. Gastric carcinoma. In: Haboubi N. Pathology and genetics: Tumours of the digestive system. Surg Oncol. 2000; 9:144-145. https://doi.org/10.1016/S09607404(01)00003-2

15. Sekine S, Shibata T, Yamauchi $Y$, Nakanishi $Y$, Shimoda T, Sakamoto M, et al. $\beta$-Catenin mutations in sporadic fundic gland polyps. Virchows Archiv. 2001; 440:381-386.

https://doi.org/10.1007/s004280100527

16. Stolte M, Sticht T, Eidt S, Ebert D and Finkenzeller G. Frequency, location, and age and sex distribution of various types of gastric polyp. Endoscopy. 1994; 26:659- 665. https://doi.org/10.1055/s-2007-1009061

17. Deppisch LM and Rona VT. Gastric epithelial polyps. A 10-year study. J Clin Gastroenterol. 1989; 11:110-115. https://doi.org/10.1097/00004836-198902000-00028

18. Roseau G, Ducreux M, Molas G, Ponsot P, Amouyal P, Palazzo L, et al. Epithelial gastric polyps in a series of 13000 gastroscopies. Presse Med 1990; 19:650-654.

19. Peretz A, Fuchs T, Livovsky DM, Turvall E, Pappo O and Ackerman Z. The changing histological pattern of gastric polyps in an ethnically heterogeneous population. Scand J Gastroenterol. 2012; 47:907-913.https://doi.org/10.3109/00365 521.2012.682091

20. Fan NN, Yang J, Sun G, Lu ZS, Ling Hu EQ, Wang XD, et al. Changes in the spectrum of gastric polyps in the Chinese population. World J Gastroenterol. 2015;21(33):9758-9764. https://doi.org/10.3748/wjg.v21.i33.9758

21. Tran-Duy A, Spaetgens B, Hoes AW, de Wit NJ and Stehouwer CDA. Use of proton pump inhibitors and risk of fundic gland polyps and gastric cancer: Systematic review and metaanalysis. Clin Gastroenterol Hepatol. 2016; 14:1706-1719. https://doi.org/10.1016/j.cgh.2016.05.018

22. Choudhry U, Boyce HW and Coppola D. Proton Pump InhibitorAssociated Gastric Polyps: A Retrospective Analysis of Their Frequency, and Endoscopic, Histologic, and Ultrastructural Characteristics. Am J Clin Pathol. 1998; 110:615-621. https://doi.org/10.1093/ajcp/110.5.615

23. Zelter A, Fernandez JL, Bilder C, Rodriguez P, Wonaga A, Dorado F, et al. S1082 Fundic Gland Polyps and Association with Proton Pump Inhibitor Intake: A Prospective Study in 1,780 Upper Gastroduodenal Endoscopies. Gastroenterology. 2009; 136(5). https://doi.org/10.1016/S0016-5085(09)60832-5

24. Cats A, Edschenk B, Bloemena E, Roosendaal R, Lindeman J, Biemond I, et al. Parietal cell protrusions and fundic gland cysts during omeprazole maintenance treatment. Hum Pathol. 2000; 31:684-690. https://doi.org/10.1053/hupa.2000.7637

25. Jalving M, Koornstra JJ, Wesseling J, Boezen HM, Jong SD and Kleibeuker JH. Increased risk of fundic gland polyps during long-term proton pump inhibitor therapy. Aliment Pharmacol 
Ther. 2006; 24:1341-1348. https://doi.org/10.1111/j.13652036.2006.03127.x

26. Declich P, Tavani E, Bellone S, Porcellati M, Pastori L, Omazzi B, et al. Sporadic fundic gland polyps: what happened before? Gut. 2004; 53:1721.

27. Vieth $\mathrm{M}$ and Stolte $\mathrm{M}$. Fundic Gland Polyps are not induced by Proton Pump Inhibitor Therapy. Am J Clin Pathol. 2001; 116:716720. https://doi.org/10.1309/XFWR-LXA7-7TK1-N3Q8

28. Rubio CA. Plugs clog the glandular outlets in fundic gland polyps. Int J Clin Exp Pathol. 2010; 3:69-74.

29. Odze R, Marcial $M$ and Antonioli D. Gastric fundic gland polyps: A morphological study including mucin histochemistry, stereometry, and MIB-1 immunohistochemistry. Hum Pathol. 1996; 27:896-903.

https://doi.org/10.1016/S0046-8177(96)90215-4

30. Graham DY and Genta RM. Long-term proton pumps inhibitors use and gastrointestinal cancer. Curr Gastroenterol Rep. 2008; 10:543-547. https://doi.org/10.1007/s11894-008-0100-1
31. Kumar KR, lqbal R, Coss E, Park C, Cryer B and Genta RM. Helicobacter gastritis induces changes in the oxyntic mucosa indistinguishable from the effects of proton pump inhibitors. Hum Pathol. 2013; 44:2706-2710.

https://doi.org/10.1016/j.humpath.2013.07.015

32. Declich P, Belloni J, Tavani E, Omazzi B, Bortoli A, Devani M, et al. Fundic gland polyps and proton pump inhibitors: an obvious link, or an open question? Hum Pathol. 2014; 45:11221123. https://doi.org/10.1016/j.humpath.2013.11.020

33. Genta RM, Schuler CM, Robiou $\mathrm{Cl}$ and Lash RH. No Association between Gastric Fundic Gland Polyps and Gastrointestinal Neoplastic in a Study of Over 100,000 Patients. Clin Gastroenterol Hepatol. 2009; 7:849-854.https://doi. org/10.1016/j.cgh.2009.05.015

34. Watanabe N. Regression of fundic gland polyps following acquisition of Heli-cobacter pylori Gut. 2002; 51:742-745. https://doi.org/10.1136/gut.51.5.742

\section{Authors Contribution:}

ZW, MM-Concept and design of the study, prepared first draft of manuscript; MM, AK, IB and SM- Interpreted the results; reviewed the literature and manuscript preparation; MM, AK, MR, SL and AR- Coordination, review of literature and manuscript preparation; ZA, MM- Statistically analysed and interpreted, preparation of manuscript and revision of the manuscript

\section{Work attributed to:}

Noora super-speciality, Hospital, Srinagar, Jammu Kashmir, India

\section{Orcid ID:}

Dr. Zeeshan Wani- (i) https://orcid.org/0000-0002-1096-2874

Dr. Muzzafer Mir- (D) https://orcid org/0000-0002-0412-4364

Dr. Afaq Khan- (i) https://orcid.org/0000-0001-5931-4969

Dr. Iqbal Baba- (D) https://orcid.org/0000-0002-3302-4725

Dr. Showkat Mir- (D) https://orcid.org/0000-0003-1761-1994

Dr. Majid Rather- (i) https://orcid.org/0000-0001-7814-1928

Dr. Shaheen Lone- (1) https://orcid.org/0000-0002-6550-8724

Dr. Akhter Raina- (D) https://orcid.org/0000-0002-1965-8027

Source of funding: Nil, Conflict of Interest: None declared. 